\title{
THE IMPLEMENTATION OF STAD-TYPE COPERATIVE LEARNING MODEL TO IMPROVE STUDENTS' CRITICAL THINKING AND COLLABORATIVE SKILLS
}

\author{
Vinsensius Willy Yudhanta ${ }^{1}$, Maria Melani Ika Susanti², Maria Indarti Rustamti ${ }^{3}$ \\ 1,2 Universitas Sanata Dharma, Yogyakarta, Indonesia \\ ${ }^{3}$ SD Kanisius Kalasan, Yogyakarta, Indonesia \\ Ivinsensiuswily@gmail.com, ${ }^{2}$ maria.melani.ika@gmail.com, ${ }^{3}$ iin.indarti85@gmail.com
}

\begin{abstract}
The purposes of this study were: (1) To describe efforts to improve students' critical thinking and collaborative skills in the science subject at grade $V$ SD Kanisius Kalasan in the even semester academic year 2020/2021; (2) To improve the students' critical thinking skills through STAD-type cooperative learning model; (3) To improve the collaboration ability of grade V students through STAD-type cooperative learning model in science subject, especially the material of theobject's shape changes. This research was a Classroom Action Research, conducting in two cycles following the stages of planning, implementing, observing, and reflecting. Data were collected through interviews, observation, and tests. Then, the data were analyzed by using quantitative and qualitative analysis. The results showed: (1) the efforts to improve students 'critical thinking and collaboration, (2) STAD-type cooperative learning model improved students' critical thinking skills; the mean score of the students' critical thinking in the pre-cycle was 68.80; the score in cycle I was 76; and it increased to 79.36 in cycle II, (3) STAD-type cooperative learning model improved students' collaboration skills; the mean score in pre-cycle was 69.36; it increased to 84.46 in cycle I and increased to 86.25 in cycle II.
\end{abstract}

Keywords: critical thinking, collaboration, STAD-type cooperative learning model

\section{IMPLEMENTASI MODEL PEMBELAJARAN KOOPERATIF DENGAN TIPE STAD UNTUK MENINGKATKAN KEMAMPUAN BERPIKIR KRITIS DAN KOLABORASI SISWA}

\begin{abstract}
ABSTRAK
Tujuan Penelitian ini adalah: (1) Mendeskripsikan upaya peningkatan kemampuan berpikir kritis dan kolaborasi siswa pada mupel IPA materi perubahan wujud benda kelas V SD Kanisius Kalasan semester genap tahun ajaran 2020/2021. (2) Meningkatkan kemampuan berpikir kritis siswa kelas V melalui model pembelajaran kooperatif tipe STAD. (3) Meningkatkan kemampuan kolaborasi siswa kelas V melalui model pembelajaran kooperatif tipe STAD pada mupel IPA materi perubahan wujud benda. Penelitian ini merupakan Penelitian Tindakan Kelas, dua siklus dengan tahap perencanaan, pelaksanaan, observasi, dan refleksi. Teknik pengumpulan data melalui wawancara, observasi, dan tes. Teknik analisis data menggunakan analisis kuantitatif dan kualitatif. Hasil penelitian menunjukkan: (1) Upaya peningkatan berpikir kritis dan kolaborasi siswa. (2) Penerapan model pembelajaran kooperatif tipe STAD dapat meningkatkan kemampuan berpikir kritis siswa; rerata berpikir kritis siswa pada prasiklus sebesar 68.80; pada siklus I sebesar 76; dan meningkat menjadi 79.36 pada siklus II. (3) Penerapan model pembelajaran kooperatif tipe STAD dapat meningkatkan kemampuan kolaborasi siswa; nilai rerata prasiklus adalah 69.36; meningkat menjadi 84.46 pada siklus I; dan meningkat menjadi 86.25 pada siklus II.
\end{abstract}

Kata Kunci: Berpikir kritis, kolaborasi, model pembelajaran kooperatif tipe STAD

\begin{tabular}{|c|c|c|}
\hline Submitted & Accepted & Published \\
\hline 12 Februari 2021 & 11 Juli 2021 & 28 Juli 2021 \\
\hline
\end{tabular}

\begin{tabular}{|l|c|c|}
\hline Citation & $:$ & $\begin{array}{r}\text { Yudhanta, V.W., Susanti, M.M.I., \& Rustamti, M.I. (2021). The Implementation of STAD-Type Cooperative Learning } \\
\text { Model to Improve Students' Critical Thinking and Collaborative Skills. Jurnal PAJAR (Pendidikan dan } \\
\text { Pengajaran), 5(4), 1019-1027. DOI : http://dx.doi.org/10.33578/pjr.v5i4.8441. }\end{array}$ \\
\hline
\end{tabular}

\section{PENDAHULUAN}

Pendidikan pada abad ke-21 saat ini menjadi suatu hal yang dapat menciptakan peserta didik untuk memiliki keterampilan belajar dan berinovasi, menggunakan teknologi dan media informasi, serta dapat bekerja, dan bertahan dengan menggunakan keterampilan untuk hidup (life skills) (Kemdikbud, 2013: 5). Pendidikan yang mampu mendukung manusia dalam persaingan global adalah pendidikan yang mengembangkan potensi peserta didik. Pengembangan tersebut tidak hanya dalam kemampuan akademik, namun juga dalam pengembangan kemampuan lainnya, seperti kreativitas, komunikasi, kerjasama, dan adaptasi 
(Cahyono, 2014: 1). Mempersiapkan peserta didik yang berkualitas dapat melalui proses pendidikan sains sehingga peserta didik memiliki keterampilan berpikir kritis (Pratiwi, 2015: 1). Keterampilan yang dipilih untuk ditingkatkan dalam penelitian ini adalah keterampilan berpikir kritis dan keterampilan kolaborasi. Berpikir kritis merupakan keterampilan penting yang dibutuhkan dalam dunia kerja. Kemampuan ini menduduki urutan pertama dalam daftar keterampilan yang dibutuhkan. Keterampilan komunikasi, kolaborasi, kesadaran global, penguasaan teknologi, keterampilan dalam hidup dan karir, kemampuan belajar dan inovasi membutuhkan fondasi berpikir kritis yang baik. Pentingnya konstruk berpikir kritis dalam dunia pendidikan maupun pekerjaan memang tidak lagi perlu diperdebatkan. Meskipun demikian pendefinisian maupun bagaimana konstruk berpikir kritis tersebut diukur masih menjadi perdebatan para ahli di bidang psikologi, filsafat maupun pendidikan (Rochmad dkk, 2018).

Kemampuan kolaborasi saat ini menjadikan kerjasama sebagai suatu struktur interaksi yang dirancang sedemikian rupa guna memudahkan usaha kolektif untuk mencapai tujuan bersama. Kolaborasi telah menjadi keterampilan yang penting untuk mencapai hasil yang efektif. Melalui kolaborasi, peserta didik memiliki kemampuan bekerjasama dan sosial untuk mencapai tujuan pembelajaran (Nea: 2007: 19-20). Kemampuan kolaborasi sangat penting dilatihkan sejak awal kepada peserta didik. Dengan adanya proses kolaborasi dalam pembelajaran, peserta didik dapat mengembangkan kemampuan sosial untuk memecahkan permasalahan secara bersama-sama. Berdasarkan hasil wawancara terhadap guru kelas V di SD Kanisius Kalasan Yogyakarta, mata pelajaran yang banyak digemari oleh siswa yaitu IPA. Dalam gaya belajar yang digunakan, guru biasanya menugaskan siswa untuk memecahkan suatu masalah dengan cara berkelompok. IPA merupakan salah satu mata pelajaran yang ada pada semua jenjang pendidikan, mulai dari tingkat sekolah dasar hingga perguruan tinggi. Pembelajaran IPA sangat penting diberikan kepada siswa tingkat SD dengan tujuan, yaitu: (1) Memberikan pengetahuan kepada siswa tentang dunia tempat hidup dan bagaimana bersikap; (2) menanamkan sikap hidup ilmiah; (3) memberikan keterampilan untuk melakukan pengamatan; (4) mendidik siswa untuk mengenal, mengetahui cara kerja serta menghargai para ilmuwan penemunya; dan (5) menggunakan dan menerapkan metode ilmiah dalam memecahkan permasalahan (Trianto dalam Hazmiwati, 2018: 178).

Berdasarkan hasil wawancara terhadap guru kelas V di SD Kanisius Kalasan Yogyakarta, menunjukkan bahwa gaya belajar yang paling diminati oleh peserta didik yaitu diskusi kelompok. Akan tetapi di dalam melakukan kegiatan kelompok pasti ada salah satu peserta didik yang memiliki daya tangkap kurang sehingga terkadang tertinggal dengan temanteman kelompok yang lain. Kemudian, keterampilan berpikir kritis yang dimiliki oleh peserta didik masih kurang, atau terbilang belum merata. Berawal dari permasalahan tersebut, kemudian peneliti menggali data lebih dalam mengenai rendahnya kemampuan berpikir kritis dan kolaborasi siswa.

Data awal berpikir kritis siswa diperoleh melalui penyebaran kuisioner pada saat kegiatan pembelajaran melalui platform Zoom berlangsung. Terdapat 5 indikator kemampuan berpikir kritis yang digunakan sebagai acuan pengamatan. Dari sebanyak 46 siswa yang diamati, diketahui bahwa persentase ketuntasan ulangan untuk menilai berpikir kritis siswa adalah sebesar $34.04 \%$ dalam kategori kurang kritis. Selanjutnya, peneliti mengamati dokumen nilai ulangan siswa pada tahap prasiklus dan diketahui nilai rerata siswa sebesar 68.80. Selain itu, diketahui bahwa dari sebanyak 46 Siswa terdapat 16 siswa yang mencapai nilai 75 atau mencapai kriteria ketuntasan minimal (KKM). Kemudian untuk data awal kolaborasi siswa diperoleh melalui penyebaran kuisioner setelah kegiatan kerja kelompok atau diskusi kelompok selesai. Terdapat 7 indikator kemampuan kolaborasi yang digunakan sebagai acuan pengamatan. Dari sebanyak 46 siswa yang diamati, diketahui bahwa 
rerata kemampuan kolaborasi siswa adalah sebesar 69.36 dalam kategori kolaboratif.

Permasalahan tersebut mendorong peneliti untuk meningkatkan kemampuan berpikir kritis dan kolaborasi siswa dengan menerapkan model pembelajaran kooperatif tipe STAD. Menurut Suryanti, dkk (2009: 16) pembelajaran kooperatif tipe $S T A D$ merupakan sebuah model pembelajaran yang berangkat dari pembelajaran yang bersifat teacher centered menuju pembelajaran student centered. Pembelajaran dilakukan dengan menggunakan kelompokkelompok kecil dengan jumlah anggota tiap kelompok 4-5 orang peserta didik secara heterogen, yang merupakan campuran tingkat prestasi, jenis kelamin, latar belakang sosial, dan suku. Model pembelajan ini menekankan pada aktivitas kerja sama peserta didik dalam belajar yang terbentuk dalam kelompok kecil yang mempelajari materi pelajaran dan memecahkan masalah secara kolektif yang disertai iklim belajar yang terbuka dan demokratis sehingga memberikan kesempatan optimal bagi peserta didik untuk memperoleh banyak informasi sekaligus melatih sikap dan keterampilan sosialnya sebagai bekal dalam kehidupan bermasyarakat.

Berdasarkan uraian tersebut, penelitian ini bertujuan untuk 1) meningkatkan kemampuan berpikir kritis dan kolaborasi siswa kelas $\mathrm{V}$ pada mata pelajaran IPA melalui penerapan model pembelajaran kooperatif tipe STAD dan 2) mendiskripsikan cara meningkatkan kemampuan berpikir kritis dan kolaborasi siswa kelas $\mathrm{V}$ pada mata pelajaran IPA melalui penerapan model pembelajaran kooperatif tipe STAD.

\section{KAJIAN TEORETIS Berpikir Kritis}

Berpikir kritis merupakan sebuah proses yang terarah dan jelas yang digunakan dalam kegiatan mental seperti memecahkan masalah, mengambil keputusan, membujuk, menganalisis asumsi, dan melakukan penelitian ilmiah. Berpikir kritis dapat dikatakan sebagai (1) Kemampuan untuk berpendapat dengan cara terorganisasi, (2) Kemampuan untuk mengevaluasi secara sistematis bobot pendapat pribadi dan pendapat orang lain, (3) Kegiatan mental yang memupuk ide-ide asli dan pemahaman baru (Johnson, 2009: 183). Berpikir kritis merupakan suatu proses berpikir yang bertujuan untuk membuat keputusankeputusan yang rasional yang diyakini kebenarannya dan mengoreksi secara kritis suatu informasi baru atau suatu permasalahan. Orang yang berpikir kritis adalah seseorang yang berpikir sendiri dan bertanggung jawab atas keputusankeputusan yang diambilnya dalam kehidupan (Maryanti dan Qadriah, 2019). Berpikir kritis merupakan suatu proses berpikir yang bertujuan untuk membuat keputusankeputusan yang rasional yang diyakini kebenarannya dan mengoreksi secara kritis suatu informasi baru atau suatu permasalahan. Sedangkan Puspadewi (Putra dan Suara, 2014) mendefinisikan bahwa berpikir kritis adalah cara berpikir yang sistematis dan mandiri, yang akan menghasilkan suatu interpretasi, analisis, kesimpulan serta evaluasi terhadap suatu hal atau permasalahan. Dari beberapa pengertian tersebut dapat disimpulkan bahwa berpikir kritis adalah salah satu proses berpikir tingkat tinggi yang dapat digunakan dalam pembentukkn sistem konseptual siswa. Dengan berpikir kritis, maka pemikir kritis menelaah proses berpikir yang digunakan sudah benar (masuk akal atau tidak).

\section{Indikator Berpikir Kritis}

Menurut Angelo (dalam Achmad, 2007) mengidentifikasi lima indikator yang sistematis dalam berpikir kritis, yaitu sebagai berikut: (1) keterampilan menganalisis, (2) keterampilan mensintesis, (3) keterampilan mengenal dan memecahkan masalah, (4) keterampilan menyimpulkan, (5) keterampilan mengevaluasi dan menilai. Kemudian Wowo (2012: 198) menambahkan bahwa berpikir kritis terdiri dari beberapa indikator sebagai berikut: (1) mengidentifikasi fokus masalah, pertaanyaan, dan kesimpulan, (2) menganalisis argumen, (3) bertanya dan menjawab pertanyaan klarifikasi atau tantangan, (4) mengidentifikasi istilah keputusan dan menangani sesuai alasan, (5) mengamati dan menilai laporan observasi, (5) 
menyimpulkan dan menilai keputusan, (6) mempertimbangkan alasan tanpa membiarkan ketidaksepakatan atau keraguan yang mengganggu pemikiran (berpikir yang disangka benar), (7) mengintegrasikan kemampuan lain dan disposisi dalam membuat dan mempertahankan keputusan.

Berdasarkan pendapat dari para ahli tentang indikator kemampuan berpikir kritis tersebut, kemudian peneliti mencari kesamaan dari indikator-indikator yang sudah dijelaskan. Dari indikator-indikator tersebut kemudian peneliti memilih 5 indikator sebagai fokus penelitian, yaitu: (1) mengidentikasi fokus masalah, pertanyaan, dan kesimpulan, (2) mampu bertanya, (3) mampu menjawab pertanyaan, (4) mengamati dan menilai laporan observasi, (5) menyimpulkan dan menilai. Pemilihan lima indikator tersebut dipilih berdasarkan karakteristik peserta didik dalam pembelajaran kooperatif.

\section{Kolaborasi}

Kolaborasi saat ini menjadikan kerjasama sebagai suatu struktur interaksi yang dirancang sedemikian rupa guna memudahkan usaha kolektif untuk mencapai tujuan bersama. Kolaborasi telah menjadi kemampuan yang penting untuk mencapai hasil yang efektif. Melalui berkolaborasi, peserta didik memiliki kemampuan bekerjasama dan sosial untuk mencapai tujuan pembelajaran (Nea, 2007: 19-20). Edythe dkk (dalam Apriono, 2013: 296) menyatakan bahwa seorang pendidik harus mengajarkan kemampuan akademis dan kemampuan kerjasama kepada peserta didik, karena tindakan ini akan bermanfaat untuk meningkatkan kerja kelompok, dan menentukan keberhasilan dalam hubungan sosial di masyarakat. Keterampilan kolaborasi adalah suatu kemampuan dalam bekerja sama megerjakan sesuatu seara bersama - sama dengan satu tujuan. Jika anak semakin banyak berkesempatan melaksanakan sesuatu bersama-sama semakin cepat anak dapat belajar (Sunbanu dkk, 2019).

Dari pengertian tersebut dapat disimpulkan bahwa kolaborasi adalah bentuk kerja sama, interaksi, dan kompromi yang melibatkan banyak orang untuk mencapai hasil yang sangat baik, sesuai dengan visi bersama. Motivasi yang mendasari sebuah kolaborasi adalah tujuan yang sama, kesamaan persepsi, kemauan untuk beproses, saling memberikan manfaat, kejujuran, kasih sayang serta berbasis masyarakat.

\section{Indikator Kolaborasi}

Ahmad (2018: 5) mengidentifkasi 9 indikator yang sistematis dalam kemampuan kolaborasi siswa, yaitu sebagai berikut: (1) memiliki empati dan menghormati perspektif berbeda, (2) saling berbagi informasi yang dianggap relevan, (3) mendiskusikan jawaban sebelum mengambil keputusan, (4) memanfaatkan waktu diskusi dengan maksimal, (5) menciptakan suasana akrab dalam kelompok, (6) keputusan yang diambil adalah tanggung jawab kelompok, (7) memberikan pendapat saat proses diskusi, (8) mau menerima pendapat teman, (9) membuat laporan diskusi kelompok. Kemudian menurut Taryono (2016: 9) dalam penelitiannya menyebutkan, bahwa untuk mengetahui keberhasilan kolaborasi siswa, maka diperlukan indikator sebagai berikut: (1) memiliki tanggung jawab, (2) membantu kelompok, (3) menghormati orang lain, (4) membuat dan mengikuti perjanjian, (5) mengatur pekerjaan, (6) bekerja sebagai satu tim. Kemampuan kolaborasi diukur dengan menggunakan rubik observasi dan kolaborasi yang mengacu pada indikator tersebut.

Peneliti mencari kesamaan dari indikatorindikator yang telah dibahas dan menjadikan indikator tersebut sebagai fokus penelitian, yaitu: (1) menerima pendapat dari teman kelompok, (2) memiliki rasa tanggung jawab, (3) saling membantu anggota kelompok, (4) bekerja sebagai satu tim, (5) memanfaatkan waktu diskusi sebaik mungkin, (6) keputusan yang diambil adalah tanggung jawab kelompok, (7) mengikuti aturan kelompok yang telah dibuat.

\section{METODE PENELITIAN}

Jenis Penelitian ini adalah penelitian adalah penelitian tindakan kelas (PTK) atau Classroom Action Research (CAR). Penelitian Tindakan Kelas (PTK) adalah jenis penelitian yang direncanakan namun dilakukan oleh guru di dalam 
kelas dengan tujuan meningkatkan kinerja guru sehingga terdapat peningkatan hasil belajar pada siswa (Wardani dan Wihardit, 2010: 9). Jenis penelitian PTK dilaksanakan minimal dalam dua siklus (Arikunto, 2010: 8). Penelitian ini menggunakan jenis penelitian tindakan kelas berbentuk siklus dimana model penelitian bertahap dari siklus satu ke siklus berikutnya (Kemmis dan Mc. Taggart dalam Arikunnto, 2010: 132). Setiap siklus meliputi Planning (rencana), Action (tindakan), Observation (observasi) dan Reflektion (refleksi). Kerangka penelitian ini menggunakan model penelitian tindakan kelas yang terdiri dari 2 siklus pada pembelajaran IPA materi perubahan wujud benda. Setiap siklus terdiri dari 4 langkah yaitu langkah perencanaan, pelaksanaan, observasi, dan refleksi. Siklus kedua dilakukan untuk memperbaiki segala sesuatu yang belum baik dan berakhir pada siklus pertama.

Teknik pengumpulan data tes diperoleh dari rata-rata soal evaluasi siklus I dan siklus II serta persentase siswa yang mencapai KKM. Data hasil belajar diperoleh dengan tes objektif berbentuk pilihan ganda. Penghitungan penskoran ditentukan jika jawaban benar memperoleh skor 1 dan untuk jawaban salah memperoleh skor 0. Pada siklus I terdapat 2 soal evaluasi di setiap pertemuannya. Pada siklus 1 pertemuan I memberikan 1 soal evaluasi dan pada pertemuan 2 memberikan 1 soal evaluasi dengan masingmasing soal terdapat 10 butir pertanyaan pilihan ganda, dan pada siklus 2 pertemuan I memberikan 1 soal evaluasi, pada pertemuan II memberikan 1 soal evaluasi yang dimana masing-masing soal terdapat 10 butir pertanyaan pilihan ganda. Berikut ini adalah pedoman penskoran soal evaluasi:

$$
\text { Nilai }=\frac{\text { Jumlah skor yang benar }}{\text { Jumlah skor total }} \times 100
$$

Menghitung rata-rata hasil belajar siswa secara keseluruhan dengan rumus:

Rata-rata nilai $=\frac{\text { Jumlah nilai seluruh siswa }}{\text { Jumlah siswa }}$

Menghitung presentase siswa yang mencapai KKM dengan menggunakan rumus:

Persentase $=\frac{\text { Jumlah siswa yang mencapai } K K M}{\text { Jumlah seluruh siswa }} \times 100 \%$

Teknik pengumpulan data non tes berdasarkan hasil kuesioner kemampuan berpikir kritis dan kolaborasi. Kuisioner kemampuan berpikir kritis siswa yang digunakan dalam penelitian ini terdiri dari 13 pertanyaan dengan 5 indikator yang diukur. Kemampuan kolaborasi terdiri dari 14 pertanyaan dengan 7 indikator yang diukur. Masing-masing pertanyaan terdapat 2 pilihan jawaban yang terdiri dari Ya dan Tidak.

Peneliti menggunakan rumus sebagai berikut untuk menghitung nilai kuisioner berpikir kritis dan kolaborasi siswa:

Nila rata-rata $=\frac{\text { Jumlah siswa yang mampu bekerja sama }}{\text { Jumlah total siswa }} \times 100 \%$

Peneliti membuat 5 interval untuk menentukan kriteria berpikir kritis siswa. Kriteria berpikir kritis siswa dapat dilihat pada tabel berikut ini:

Tabel 1. Kriteria Berpikir Kritis Siswa

\begin{tabular}{ll}
\hline \multicolumn{1}{c}{ Persentase(\%) } & \multicolumn{1}{c}{ Kategori } \\
\hline$>80$ & Sangat kritis \\
\hline$>80-60$ & Kritis \\
\hline$>60-40$ & Cukup kritis \\
\hline$>40-20$ & Kurang kritis \\
\hline$\leq 20$ & Sangat Kurang \\
\hline
\end{tabular}

Sedangkan untuk konversi interval kriteria kolaborasi siswa peneliti menggunakan persentase sebagai berikut: 


\begin{tabular}{cl}
\multicolumn{2}{l}{ Tabel 2. Kriteria Kemampuan Kolaborasi Siswa } \\
\hline \multicolumn{1}{c}{ Persentase $\mathbf{( \% )}$} & \multicolumn{1}{c}{ Kategori } \\
\hline $80<X \geq 100$ & Sangat kolaboratif \\
\hline $60<X \leq 80$ & Kolaboratif \\
\hline $40<X \leq 60$ & Cukup Kolaboratif \\
\hline $20<X \leq 40$ & Kurang kolaboratif \\
\hline $0<X \leq 20$ & Sangat Kurang \\
\hline
\end{tabular}

\section{HASIL DAN PEMBAHASAN}

Hasil penelitian prasiklus didapat dari wawancara terhadap guru kelas VA dan VB SD Kanisius Kalasan dengan tujuan mengumpulkan informasi mengenai permasalahan yang ada ketika proses pembelajaran di kelas sedang berlangsung. Kemudian peneliti melakukan observasi untuk melihat secara langsung aktivitas siswa pada saat pembelajaran melalui platform Zoom. Data berpikir kritis siswa didapat dari data awal, hasil nilai evaluasi siklus I dan siklus II, serta kuesioner. Sedangkan data kolaborasi siswa diperoleh dari hasil kuesioner yang telah diisi oleh siswa kelas VA dan VB. Berdasarkan hasil kuesioner terbukti model pembelajaran kooperatif tipe STAD dapat meningkatkan kemampuan berpikir kritis dan kolaborasi siswa kelas V SD Kanisius Kalasan yang berjumlah 46 siswa. Berikut ini nilai rata-rata siklus I dan siklus II berdasarkan analisis hasil kuesioner:

Tabel 3. Perbandingan Kemampuan Berpikir Kritis Siswa pada Tiap Tahap

\begin{tabular}{lcccc}
\hline Tahapan & Rata- & Keterangan & \multicolumn{2}{c}{ Persentase } \\
& rata & & Tuntas & $\begin{array}{c}\text { Tidak } \\
\text { Tuntas }\end{array}$ \\
\hline Prasiklus & 68.80 & Cukup kritis & $34.04 \%$ & $65.95 \%$ \\
\hline Siklus I & 76 & Kritis & $63.82 \%$ & $36.17 \%$ \\
\hline Siklus II & 79.36 & Kritis & $74.46 \%$ & $25.53 \%$ \\
\hline
\end{tabular}

Berdasarkan data pada tabel di atas, diketahui ada peningkatan berpikir kritis siswa pada tiap tahapnya. Data nilai rata-rata prasiklus sebelum penelitian yaitu 69. Dari total siswa yang berjumlah 46 siswa, terdapat 16 siswa (34\%) yang mencapai nilai KKM dan 31 siswa $(66 \%)$ yang tidak mencapai nilai KKM. Diakhir pelaksanaan siklus I dengan menerapkan model pembelajaran kooperatif tipe STAD menunjukkan adanya peningkatan dalam kemampuan berpikir kritis siswa. Nilai rata-rata siswa pada siklus I adalah 76 dengan rincian terdapat sebanyak 30 siswa $(63.82 \%)$ yang mencapai nilai KKM dan siswa yang tidak mencapai kriteria KKM sebanyak 17 siswa (36.17\%). Pada akhir pelaksanaan siklus II dengan menerapkan model pembelajaran kooperatif tipe STAD menunjukkan adanya peningkatan dalam kemampuan berpikir kritis siswa. Nilai rata-rata siswa pada siklus II adalah
79.36 dengan rincian terdapat sebanyak 35 siswa (74.46\%) yang mencapai nilai KKM, sedangkan siswa yang tidak mencapai nilai KKM sebanyak 12 siswa $(25.53 \%)$.

Penelitian ini mendukung penelitian terdahulu yang dilakukan oleh Maryanti dan Qadriah (2019) yang menyatakan bahwa hasil belajar yang diperoleh dari model pembelajaran kooperatif tipe STAD dapat meningkatkan kemampuan berpikir kritis siswa dari pada menggunakan pendekatan konvensional yang ditinjau dari keseluruhan dan subkelompok siswa. Hasil penelitian ini juga didukung oleh penelitian Puspadewi dkk (2014) yang menyatakan bahwa Penerapan pendekatan kooperatif tipe STAD ternyata telah berimplikasi positif terhadap kemampuan berpikir kritis siswa. Hal ini disebabkan oleh implementasi penerapan pendekatan kooperatif tipe STAD dapat 
memberikan kesempatan siswa untuk mengembangkan ide atau gagasan dengan katakata secara verbal dan membandingkan dengan ide-ide orang lain.
Data kemampuan kolaborasi siswa diperoleh dari lembar kuisioner yang diisi oleh siswa. Penyebaran kuisioner dilakukan ketika prasiklus dan diakhir setiap siklus.

Tabel 4. Perbandingan Kemampuan Kolaborasi Siswa pada Tiap Tahap

\begin{tabular}{lcccc}
\hline Tahapan & $\begin{array}{c}\text { Rata-rata } \\
\text { Nilai }\end{array}$ & Kategori & \multicolumn{2}{c}{ Persentase } \\
Tuntas & $\begin{array}{c}\text { Tidak } \\
\text { Tuntas }\end{array}$ \\
\hline Prasiklus & 69.36 & Kolaboratif & $44.68 \%$ & $55.31 \%$ \\
\hline Siklus I & 84.46 & $\begin{array}{c}\text { Sangat } \\
\text { kolaboratif }\end{array}$ & $72.34 \%$ & $27.65 \%$ \\
\hline Siklus II & 86.25 & $\begin{array}{c}\text { Sangat } \\
\text { kolaboratif }\end{array}$ & $80.85 \%$ & $19.14 \%$ \\
\hline
\end{tabular}

Berdasarkan tabel di atas kemampuan kolaborasi siswa mengalami peningkatan pada tiap tahapnya. Prasiklus atau kondisi awal sebelum melaksanakan penelitian, rata-rata kemampuan kolaborasi siswa adalah 69.36 dengan kategori kolaboratif. Kemudian untuk persentase siswa yang tidak mencapai nilai KKM sebanyak 26 siswa $(55.31 \%)$ dan siswa yang mencapai nilai KKM sebanyak 21 siswa (44.68\%). Diakhir pelaksanaan siklus I dengan menerapkan model pembelajaran kooperatif tipe STAD menunjukkan adanya peningkatan kemampuan kolaborasi siswa. Ratarata nilai siswa pada siklus I adalah 84.46 dengan kategori sangat kolaboratif. Dengan rincian terdapat sebanyak 34 siswa (72.34\%) yang mencapai KKM dan 13 siswa (28\%) tidak mencapai nilai KKM. Pada akhir siklus II dengan menerapkan model pembelajaran kooperatif tipe
STAD menunjukkan adanya peningkatan kemampuan kolaborasi siswa. Rata-rata nilai siswa pada siklus II adalah 86.25 dengan kategori sangat kolaboratif. Kemudian untuk persentase ketuntasan ada sebanyak 38 siswa $(80.85 \%)$ yang mencapai KKMdan sebanyak 9 siswa (19.14\%) yang tidak mencapai KKM.

Variabel pada penelitian ini adalah kemampuan berpikir kritis dan kolaborasi siswa. Data kemampuan berpikir kritis dan kolaborasi siswa diperoleh pada prasiklus, siklus I dan siklus II. Setelah data yang diperoleh dibandingkan, kemudian dapat dinyatakan bahwa kemampuan berpikir kritis dan kolaborasi siswa mengalami peningkatan pada kondisi awal dan pada setiap siklusnya. Berikut adalah grafik peningkatan kemampuan berpikir kritis dan kolaborasi siswa.

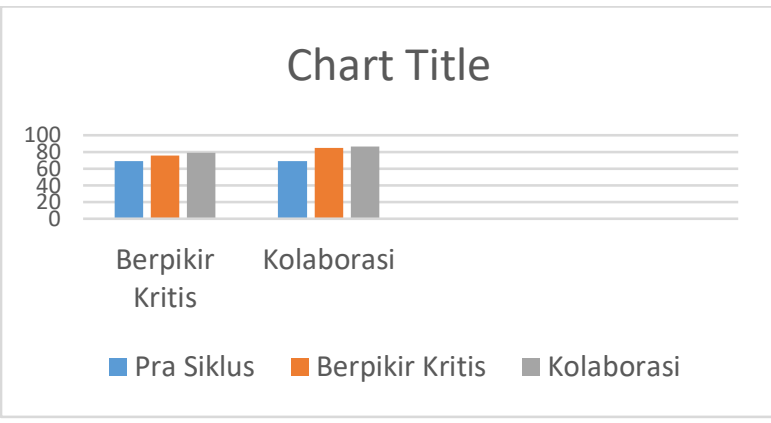

Gambar 1. Grafik Kemampuan Berpikir Kritis Dan Kolaborasi Siswa 
Hasil penelitian ini sesuai dengan penelitian yang terdahulu, yakni peneltian yang dilakukan oleh Suara, dkk (2014). Hasil peneltian menunjukkan bahwa kemampuan berpikir kritis siswa mengalami peningkatan melalui pendekatan kooperatif tipe STAD. Hal ini dapat dibuktikan dari rata-rata kemampuan berpikir kritis siswa mengalami peningkatan dari siklus I ke siklus II yaitu dari $71.02 \%$ pada siklus I menjadi $81.30 \%$ pada siklus II sehingga berada pada kategori tinggi. Selain itu penelitian ini juga mendukung penelitian terdahulu yang dilakukan oleh Sunbanu, dkk (2019) yang menyatakan bahwa keterampilan kolaborasi siswa dapat meningkat ketika menggunakan model pembelajaran kooperatif dan siswa menjadi lebih aktif ketika melakukan kegiatan pembelajaran secara berkelompok.

\section{SIMPULAN DAN REKOMENDASI}

Berdasarkan hasil penelitian, peneliti menyimpulkan bahwa penerapan model pembelajaran kooperatif tipe STAD mampu meningkatkan kemampuan berpikir kritis dan kolaborasi siswa khususnya pada mata pelajaran IPA kelas V SD Kanisius Kalasan. Hal ini dibuktikan dengan hasil penelitian dan analisis data pada variabel berpikir kritis siswa menunjukkan peningkatan dengan hasil pada data awal berpikir kritis siswa yaitu prasiklus sebesar 68.80 dengan kategori cukup kritis, siklus I sebesar 76 dengan kategori kritis dan siklus II sebesar 79.36 dengan kategori kritis. Sedangkan pada variabel kolaborasi siswa juga menunjukkan peningkatan dengan hasil rata-rata kemampuan kolaborasi siswa yaitu pada data prasiklus didapatkan hasil sebesar 69.36 dengan kategori kolaboratif, siklus I sebesar 84.46 dengan kategori sangat kolaboratif, dan siklus II sebesar 86.25 dengan kategori sangat kolaboratif. Penerapan pendekatan kooperatif tipe STAD ternyata telah berimplikasi positif terhadap kemampuan berpikir kritis siswa. Hal ini disebabkan oleh implementasi penerapan pendekatan kooperatif tipe STAD dapat memberikan kesempatan siswa untuk mengembangkan ide atau gagasan dengan katakata secara verbal dan membandingkan dengan ide-ide orang lain. Siswa tidak terlalu tergantung pada guru, akan tetapi dapat menambah kepercayaan kemampuan berpikir sendiri, menemukan informasi dari berbagai sumber dan belajar dari siswa yang lain. Selain itu dalam penerapan model pembelajaran kooperatif tipe STAD di kelas juga dapat menumbuhkan semangat belajar pada siswa khususnya ketika melakukan kerja dalam kelompok, karena selain dapat melatih siswa dalam bekerja sama juga siswa dapat bertukar pendapat dan pikiran ketika dihadapkan pada beberapa permasalahan yang ada.

Berdasarkan pada hasil penelitian dan pengujian terhadap siswa kelas $\mathrm{V}$ sekolah $\mathrm{SD}$ Kanisius Kalasan Yogyakarta, penulis memberikan saran-saran sebagai berikut; 1) kemampuan berpikir kritis dengan menggunakan model Kooperatif tipe STAD pada pembelajaran tematik materi IPA layak dipertimbangkan oleh guru terutama di tingkat SD untuk menjadi model pembelajaran alternatif dan referensi dalam memilih model pembelajaran yang disesuaikan dengan materi pembelajaran guna meningkatkan proses pembelajaran dan hasil belajar; 2) saat proses pembelajaran diharapkan pendidik dapat membentuk kelompok diskusi agar kemampuan kolaborasi siswa dapat meningkat; 3) bagi siswa, diharap agar tetap meningkatkan kemampuan kolaborasi sehingga lulusan SD tidak hanya memiliki hardskill yang baik namun juga softskill yang baik juga.

\section{DAFTAR PUSTAKA}

Abdulsyani. (2007). Sosiologi Skematika, Teori, dan Terapan. Jakarta: Pt. Bumi Aksara.

Achmad, A. (2007). Memahami Berpikir Kritis. http://ArtikelPendidikanNetwork. [diakses tanggal 18 November 2020, 08:23 WIB].

Ahmad, S. (2018). Meningkatkan Kemampuan Kolaborasi Siswa Kelas XI SMA Islam AlQodir Menggunakan Model TPS Pada Materi Sistem Reproduksi. Kediri: Universitas Nusantara PGRI.

Apriono, D. (2013). Pembelajaran Kolaboratif. Jurnal Prospektus UNIROW. XVII (1): 292-304. 
Cahyono, W. (2014). Seminar Pendidikan Highscope Indonesia. http://www.highscope.or.id/PressRelease EducationSeminar. [diakses pada 18 November 2020, 19.02 WIB].

Elaine B. J. (2009). Contextual Teaching \& Learning Menjadikan Kegiatan Belajar Mengajar Mengasyikkan dan Bermakna. Bandung: MLC.

Hazmiwati. Penerapan Model Pembelajaran Kooperatif Tipe STAD Untuk Meningkatkan Hasil Belajar IPA Siswa Kelas II Sekolah Dasar. Dumai.

Kemendikbud. (2013). Bahan-bahan Sosialisai Kurikulum 2013. Jakarta.

Maryanti \& Qadriah,L. (2019). Peningkatan Kemampuan Berpikir Kritis dan Logis Matematik Siswa SMK Negeri 1 Sigli Melalui Model Kooperatif Tipe STAD Berbantuan Maple. http://journal.unigha.ac.id/index.php/JSR/ article/view/109. [diakses pada 26 Januari 2021, 09.48 WIB].

Nea. (2007). Preparing 21st Century Students for a Global Society: An Educator's Guide to the "Four Cs". London: Pearson.

Pratiwi, U. (2015). Pengembangan Instrumen Penilaian HOTS Berbasis Kurikulum 2013 Terhadap Sikap Disiplin. Jurnal Penelitian dan Pembelajaran IPA. 1 (1); 1-12. Jakarta.

Puspadewi, A.A.I., Putra, I.M., Suara, I.M. Peningkatan Kemampuan Berpikir Kritis Melalui Pendekatan Pembelajaran Kooperatif Tipe Student Teams Achievement Division Pada Mata Pelajaran PKn Siswa Kelas V SDN 2 Blahbatuh.

https://ejournal.undiksha.ac.id/index.php/J JPGSD/article/view/4339. [diakses pada 26 Januari 2021, 09.54 WIB].

Rochmad E, J, B. (2018). Meningkatkan Kemampuan Berpikir Kritis Melalu Problem Based Learning Dengan Peer Feedback Activity. Jurnal Elektronik Pembelajaran Matematika. Semarang: Universitas Negeri Semarang.
Suara, I.M., Puspadewi A.A.I., Putra, I.M. (2014). Peningkatan Kemampuan Berpikir Kritis Melalui Pendekatan Pembelajaran Kooperatif Tipe STAD Pada Mata Pelajaran Pkn Siswa Kelas V SD N 2 Blahbatuh. Universitas Ganesha.

Sunbanu, H.F., Mawardi., Wardani, K.W. (2019) Peningkatan Keterampilan Kolaborasi Siswa Menggunakan Model Pembelajaran Kooperatif Two Stay Two Stray Di Sekolah Dasar.

https://jbasic.org/index.php/basicedu/artic le/view/260/pdf. [diakses pada 27 Januari 2021, 19.45WIB].

Taryono. (2016). Penerapan Pembelajaran Berbasis Proyek Dan Pembelajaran Berbasis Masalah Pada Mata Pelajaran Fisika Untuk Meningkatkan Keterampilan Abad 21 (4C) Siswa SMP. Universitas Pendidikan Indonesia: Perpustakaan.upi.edu.

Zubaidah, S. (2016). Keterampilan Abad Ke-21: Keterampilan Yang Diajarkan Melalui Pembelajaran. E-Jurnal 1-17 hlm. 